ISSN: 2224-0616

Int. J . Agril. Res. Innov. \& Tech. 4 (2): 11-15, December, 2014 Available online at http:// www.ijarit.webs.com

\title{
EFFECTS OF ARTIFICIAL FEEDS ON GROWTH AND PRODUCTION OF FISHES IN POLYCULTURE
}

\author{
M.A. Hosen"1,2, M. Shahjahan" ${ }^{*}$, M.S. Rahman1 and M.J. Alam¹,2 \\ Received 18 June 2014, Revised 1 November 2014, Accepted 22 December 2014, Published online 31 December 2014
}

\begin{abstract}
A study on the effects of artificial feeds on growth and production of fishes along with some limnological conditions were conducted in polyculture system. Species of Indian major carp (Cirrhinus mrigala) and exotic fishes (Hypophthalmicthys molitrix and Oreochromis niloticus) were stocked in six ponds under two treatments, each with three replications. Stocking rate in both treatments was 100 fish per decimal at the ratio of silver carp: tilapia: mrigal $=2: 2: 1$. Fertilization and artificial feeds were given in Ttreatment 1 (T1) and only fertilization was done in Treatment 2 (T2). Wheat bran, rice bran and soybean meal were given daily as artificial feed in T1 in the ratio of wheat bran: rice bran: soybean meal $=2: 2: 1$ (by wt). Urea, T.S.P and cow dung were applied fortnightly at the rate of $60 \mathrm{~g} \mathrm{deci-}^{-1}, 90 \mathrm{~g}$ deci- $^{-1}$ and $2 \mathrm{~kg} \mathrm{deci}^{-1}$ respectively. Water temperature, transparency, $\mathrm{pH}$, dissolved oxygen, free $\mathrm{CO}_{2}$, total alkalinity, $\mathrm{PO}_{4}-\mathrm{P}$ and $\mathrm{NO}_{3}-\mathrm{N}$ were determined fortnightly and phytoplankton and zooplankton were studied fortnightly. These limnological conditions were more or less similar in the ponds under two treatments and were within suitable ranges. Calculated gross and net yields of fish were 16.56 and 12.48 ton ha- $^{-1}$ respectively in case of fertilization and

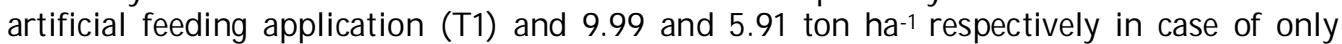
fertilization (T2). Application of artificial feed in T1 significantly increased the growth and production of fish more than two times which indicates that artificial feeding in polyculture is very useful for increasing fish production.
\end{abstract}

Keywords: Artificial Feed, Aquaculture, Polyculture, Fertilizer, Water Quality

\footnotetext{
${ }^{1}$ Department of Fisheries Management, Bangladesh Agricultural University, Mymensingh-2202, Bangladesh

${ }^{2}$ Department of Fisheries, Ministry of Fisheries and Livestock, Dhaka, Bangladesh

*Corresponding author's email: mdshahjahan@bau.edu.bd (M. Shahjahan)
}

\section{Introduction}

Aquaculture in Bangladesh has rapidly progressed in recent years with a contribution of $44 \%$ to the annual fish production (DoF, 2012). Among different techniques of aquaculture, polyculture is one of the most important techniques. The basic principle of fish polyculture systems rests on the idea that when compatible species of different feeding habits are cultured together in the same pond, the maximum utilization of all natural food sources takes place without harmful effects. Polyculture or mixed culture of carps has been found as an economically viable and technically sustainable in perennial water bodies (Alikunhi, 1957; Chen, 1976). The selection of fish species is very important for polyculture systems. In the present study, tilapia (Oreochromis niloticus), silver carp (Hypophthalmicthys molitrix), and mrigal (Cirrhinus mrigala) were selected for polyculture. These species are suitable for low inputs culture system in small ponds and ditches for their quick growth and maximum production within short period (4-6 months). Bangladesh has numerous seasonal water bodies in the form of shallow ponds, ditches, roadside canals, pits in rice fields, which retain water for 4-6 months. The natural environment of Bangladesh is also suitable for growing these fish species, which can be cultured in both shallow seasonal ponds and deeper perennial ponds.

To increase the fish production, improved techniques should be applied and management practices should be developed. Fertilization is one of the most important techniques to increase the fish production. Through fertilization, natural food of fish i.e. plankton is increased. On the other hand, artificial feed application is the most important technique to increase the production. Application of fertilizers or use of supplementary feed can play a vital role to increase the fish production in polyculture system. Faluroti (1987) stated that fertilization increased the fish production in polyculture system. Gupta et al. (1990) found about double production $(4917 \mathrm{~kg}$ ha $^{-1}$ per annum) with supplementary feed than that of without supplementary feed ( $2583 \mathrm{~kg} \mathrm{ha}^{-1}$ per annum) in the polyculture of Indian and exotic carp. The ingredients that are easily 
available and are of comparatively low price are used as supplementary feed. The most easily available ingredients are rice bran, wheat bran, soybean meal that is appropriate for Indian major carps and exotic fishes of the South Asian region. Developed and scientific fish culture and successful fisheries management depends on the various information of limnological factors of water body. These limnological factors are water quality, microorganisms, plankton, benthos etc. According to Hickling (1968), fish farming is a practical application of limnology and freshwater biology. Reid (1971) reported that fish culture could be enhanced by the improvement of substratum by the use of fertilizers along with other pond management measures. In view of the above facts, in the present study, we examined the effects of artificial feeding on the growth and production of fishes along with limnological conditions in polyculture system.

\section{Materials and Methods}

The experiment was conducted for a period of 105 days in the earthen ponds each measuring 1 decimal $\left(40 \mathrm{~m}^{2}\right)$ area at Bangladesh Agricultural University, Mymensingh, Bangladesh.

\section{Pond preparation}

Before fish stocking water of the experimental ponds were drained out to eradicate all the undesirable fishes, renovated and liming was done in all the ponds at the rate of $1 \mathrm{~kg} 40 \mathrm{~m}^{-2}$. Ponds were filled up with deep tube-well water and fertilized with cow dung $10 \mathrm{~kg}$, urea $100 \mathrm{~g}$ and TSP $100 \mathrm{~g}$ per decimal as initial doses.

\section{Stocking of fish}

Ponds were stocked at a stocking density of 100 fingerlings per decimal $\left(40 \mathrm{~m}^{2}\right)$ at the ratio of tilapia: silver carp: mrigal =2: $2: 1$.

\section{Fertilization and supply of artificial feed}

The ponds were fertilized fortnightly with cow dung $2 \mathrm{~kg}$, urea $60 \mathrm{~g}$ and TSP $90 \mathrm{~g}$ per $40 \mathrm{~m}^{2}$ to grow natural food, phytoplankton and zooplankton. Three ingredients such as wheat bran, rice bran and soybean meal were applied as supplementary feed once daily in the morning between 8.00 and 9.00 a.m. The required amount of feed was mixed with a little amount of water to make it into thick 'dough' rolled into balls. The balls were then thrown into the ponds. Supplementary feed was supplied in T1 and T2 was control (no supplementary feed was supplied). Feed was supplied every day at the rate of $5 \%$ of the total fish biomass. Fish sampling was carried out at an interval of 15 days in order to calculate the increase in total wt. and to adjust the amount of feed. Ratio of artificial feed ingredients was, wheat bran: rice bran: soybean meal =4: 4: 2 (by wt.).

\section{Physico-chemical parameters}

Various physical and chemical parameters of the ponds such as water temperature $\left({ }^{\circ} \mathrm{C}\right)$, transparency $(\mathrm{cm})$, dissolved oxygen $\left(\mathrm{mg} \mathrm{L}^{-1}\right)$, $\mathrm{pH}$, free $\mathrm{CO}_{2}\left(\mathrm{mg} \mathrm{L}^{-1}\right)$, total alkalinity (mg L-1), $\mathrm{PO}_{4}-\mathrm{P}\left(\mathrm{mg} \mathrm{L}^{-1}\right)$ and $\mathrm{NO}_{3}-\mathrm{N}\left(\mathrm{mg} \mathrm{L}^{-1}\right)$ were estimated fortnightly. Water temperature was recorded with a Celsius thermometer and transparency was measured with a Secchi disc of $30 \mathrm{~cm}$ diameter. Dissolved oxygen was measured directly with a DO meter (Lutron, DO-5509) and a portable digital $\mathrm{pH}$ meter was used to measure $\mathrm{pH}$. Free $\mathrm{CO}_{2}$ and total alkalinity were determined by titrimetric method (APHA, 1992). $\mathrm{PO}_{4}-\mathrm{P}\left(\mathrm{mg} \mathrm{L}^{-1}\right)$ and $\mathrm{NO}_{3}-\mathrm{N}\left(\mathrm{mg} \mathrm{L}^{-1}\right)$ were determined by a Hach Kit (DR/2010, a direct reading Spectrophotometer).

\section{Study of planktons}

Biological parameters of the ponds such as phytoplankton density (cells $\mathrm{L}^{-1}$ ) and zooplankton density (cells $\mathrm{L}^{-1}$ ) were estimated fortnightly. The counting of plankton (both phytoplankton and zooplankton) was done with the help of Sedgwick-Rafter Counting Cell (S-R cell) under a compound binocular microscope. The plankton population was determined by using the formula of Rahman (1992). Identification of plankton (phytoplankton and zooplankton) up to generic level were made according to Prescott (1964), Needham and Needham (1963) and Belcher and Swale (1978).

\section{Study of growth and production of fish}

At the end of the experiment, all fish were harvested through repeated netting by a seine net to calculate gross and net production of fish.

Specific growth rate (SGR, \% per day) was estimated by the following formula:

$$
\text { SGR }(\% \text { per day })=\frac{\text { Loge } W_{2}-\text { Loge } W_{1}}{T_{2}-T_{1}} \times 100
$$

Where, $\mathrm{W}_{1}=$ Initial live body weight $(\mathrm{g})$ at time $\mathrm{T}_{1}$ (day) $\mathrm{W}_{2}=$ Final live body weight $(\mathrm{g})$ at time $\mathrm{T}_{2}$ (day)

\section{Statistical analysis}

A computer using SPSS package programme did T-test of net fish production of the ponds under $\mathrm{T} 1$ and $\mathrm{T} 2$.

\section{Results}

\section{Water quality parameters}

The results of physico-chemical parameters are shown in Table 1 . All physical and chemical parameters of the ponds were found to be within the acceptable ranges for fish culture in both treatments. 
Table 1. Water quality parameters (Means $\pm S D ; n=3$ ) of the ponds during the experimental period

\begin{tabular}{lrr}
\hline Parameters & Treatment 1 & Treatment 2 \\
\hline Water temperature $\left({ }^{\circ} \mathrm{C}\right)$ & $30.80 \pm 1.52$ & $31.28 \pm 1.47$ \\
Transparency $(\mathrm{cm})$ & $24.54 \pm 6.94$ & $33.25 \pm 5.98$ \\
pH & $7.21 \pm 0.16$ & $7.11 \pm 0.30$ \\
Dissolved oxygen $\left(\mathrm{mgL}^{-1}\right)$ & $5.31 \pm 0.64$ & $5.21 \pm 0.54$ \\
Free $\mathrm{CO}_{2}\left(\mathrm{mgL}^{-1}\right)$ & $4.65 \pm 0.17$ & $4.58 \pm 0.27$ \\
Total alkalinity $\left(\mathrm{mgL}^{-1}\right)$ & $99.15 \pm 9.11$ & $97.71 \pm 8.26$ \\
Phosphate-phosphorous $\left(\mathrm{mgL}^{-1}\right)$ & $0.29 \pm 0.12$ & $0.35 \pm 0.07$ \\
Nitrate-nitrogen $\left(\mathrm{mgL}^{-1}\right)$ & $1.09 \pm 0.48$ & $1.11 \pm 0.43$ \\
\hline
\end{tabular}

\section{Plankton}

Fortnightly fluctuation of phytoplankton density (cells $\mathrm{L}^{-1}$ ) and zooplankton density (cells $\mathrm{L}^{-1}$ ) are shown in Table 2. The average density of phytoplankton of the ponds under T1 was 60.95 $\pm 4.48\left(\mathrm{x} 10^{3}\right)$ cells $\mathrm{L}^{-1}$ and that of the ponds under T2 was $58.87 \pm 3.52\left(\mathrm{x} 10^{3}\right)$ cells $\mathrm{L}^{-1}$. The average density of zooplankton of the ponds under T1 was $8.23 \pm 0.79\left(\mathrm{x} 10^{3}\right)$ cells $\mathrm{L}^{-1}$ and that of the ponds under T2 was $7.92 \pm 0.60\left(\mathrm{x} 10^{3}\right)$ cells $\mathrm{L}^{-1}$. The generic status of phytoplankton and zooplankton found during the tenure of experiment are shown in Table 3. During the study period, 32 genera of phytoplankton belonging to four groups and 11 genera of zooplankton belonging to 4 groups were found in all the experimental ponds.

Table 2. Fortnightly fluctuation of phytoplankton and zooplankton densities in the ponds during the experimental period

\begin{tabular}{llrrrrrrrrr}
\hline \multirow{2}{*}{ Parameters } & Treat- & \multicolumn{10}{c}{ Sampling days } & \multirow{2}{*}{ Mean \pm SD } \\
\cline { 2 - 9 } & ments & 1 & 2 & 3 & 4 & 5 & 6 & 7 & 8 & \\
\hline Phytoplankton & T1 & 67.78 & 59.75 & 60.50 & 61.15 & 59.95 & 54.68 & 56.86 & 66.90 & $60.95 \pm 4.48$ \\
(x10 cells L-1) & T2 & 62.38 & 63.58 & 53.57 & 58.27 & 59.66 & 57.90 & 54.66 & 60.94 & $58.87 \pm 3.52$ \\
Zooplankton & T1 & 9.90 & 8.37 & 7.51 & 6.98 & 8.67 & 8.17 & 7.97 & 8.58 & $8.23 \pm 0.79$ \\
(x10 cells L $^{-1}$ ) & T2 & 8.70 & 8.60 & 7.4 & 7.50 & 7.83 & 7.33 & 7.43 & 8.53 & $7.92 \pm 0.60$ \\
\hline
\end{tabular}

Table 3. Generic status of phytoplankton and zooplankton found in the experimental ponds

\begin{tabular}{lll}
\hline & Phytoplankton & Zooplankton \\
\hline Bacillariophyceae & Chlorophyceae & Cladocera \\
Actinella & Chlorella & Daphnia \\
Asterionella & Closteriurn & Diaphanosoma \\
Coscinodiscus & Gonatozygon & Copepoda \\
Cyclotella & Oedogonium & Cyclops \\
Diatoma & Oocystis & Diaptomus \\
Fragilaria & Pediastrum & Rotifera \\
Frustularia & Scenedesmus & Asplanchna \\
Navicula & Sphaerocystis & Brachionus \\
Nitzchia & Spirogyra & Filinia \\
Tabellaria & Tetraedron & Keratella \\
Cyanophyceae & Ulothrix & Polyarthra \\
Anabaena & Volvox & Trichocerca \\
Aphanocapsa & Zygnema & Crustacean larva \\
Gleocapsa & Euglenophyceae & Nauplius \\
Gomphospaeria & Euglena & \\
Microcystis & Phacus & \\
Oscillatoria & & \\
Pleurosigma & & \\
\hline
\end{tabular}

\section{Growth and production of fish}

The details of mortality rate, growth and production of fish are presented in Tables 4 and 5. The calculated gross and net productions of fish of the ponds under T1 were 16.56 and 12.48 ton ha- ${ }^{-1}$ year ${ }^{1}$ and those of the ponds under T2 were 9.99 and 5.91 ton ha $^{-1}$ year ${ }^{1}$, respectively. 
Table 4. Stocking density, mortality (\%), initial and final weight and net and gross yield of fishes in ponds under two treatments

\begin{tabular}{llllllll}
\hline Treatments & $\begin{array}{l}\text { Species } \\
\text { stocked }\end{array}$ & $\begin{array}{l}\text { Stocking } \\
\text { density (per } \\
\text { decimal) }\end{array}$ & $\begin{array}{l}\text { Mortality } \\
\text { rate(\%) }\end{array}$ & $\begin{array}{l}\text { Average } \\
\text { initial } \\
\text { weight (g) }\end{array}$ & $\begin{array}{l}\text { Average final } \\
\text { weight (g) }\end{array}$ & $\begin{array}{l}\text { Species wise yield } \\
\text { (kg/decimal/3.5 month) }\end{array}$ \\
\hline T1 & Silver carp & 40 & 7.5 & 52.33 & 197.54 & 7.31 & Net \\
& Tilapia & 40 & 2.5 & 49.68 & 142.25 & 5.55 & 3.56 \\
& Mrigal & 20 & 5.0 & 33.75 & 169.95 & 6.46 & 5.78 \\
\hline T2 & Silver carp & 40 & 12.5 & 52.33 & 115.88 & 4.06 & 1.96 \\
& Tilapia & 40 & 5.0 & 49.68 & 98.25 & 3.73 & 1.75 \\
& Mrigal & 20 & 5.0 & 33.75 & 101.48 & 3.86 & 3.18 \\
\hline
\end{tabular}

Table 5. Calculated gross and net productions of fish

\begin{tabular}{|c|c|c|c|c|c|}
\hline \multirow{2}{*}{ Treatments } & \multicolumn{2}{|c|}{$\begin{array}{c}\text { Production } \\
\text { (kg/ deci/3.5 month) }\end{array}$} & \multicolumn{2}{|c|}{$\begin{array}{l}\text { Production } \\
\text { (ton/ ha/yr) }\end{array}$} & \multirow[t]{2}{*}{$\begin{array}{c}\% \text { increase of net production of } \\
\text { T1 over T2* }\end{array}$} \\
\hline & Gross & Net & Gross & Net & \\
\hline $\mathrm{T} 1$ & 19.32 & 14.56 & 16.56 & 12.48 & \multirow{2}{*}{$211.17 \%$} \\
\hline $\mathrm{T} 2$ & 11.65 & 6.89 & 9.99 & 5.91 & \\
\hline
\end{tabular}

*Net production (ton ha-1 $\mathrm{yr}^{-1}$ ) under T2 (control) was taken for $100 \%$.

\section{Discussion}

The present study was conducted to evaluate the effects of artificial feed on growth and production of fishes in polyculture of tilapia, silver carp and mrigal. The supply of artificial feed showed better growth and production performance.

The water quality parameters of the experimental ponds were within the productive ranges for the growth of plankton and benthos during the tenure of experiment (Table 1). Within limit productive ranges of such water quality parameters have also been observed by a number of authors (Uddin et al., 2007; Chowdhury et al., 2008; Uddin et al., 2012; Rahman et al., 2012; Talukdar et al., 2012; Siddika et al., 2012; Nupur et al., 2013) in the aquaculture ponds of BAU area which are in conformity with those of the present study.

During the study period, the gross and net production of fish of T1 (with supply of artificial feeding) were 19.32 and $14.56 \mathrm{~kg}^{2}$ deci-1 $^{-1}$ per 3.5 months respectively and those of the ponds under T2 (without supply of artificial feeding) were 11.65 and $6.89 \mathrm{~kg}^{-1 e c i-1}$ per 3.5 months respectively. The calculated gross and net productions of fish of T1 and T2 were 16.56 and 12.48 ton ha- $\mathrm{yr}^{-1}$ and 9.99 and 5.91 ton ha- $\mathrm{yr}^{-1}$ respectively. Murty et al. (1978) obtained gross and net fish productions of 4096.09 and $3858 \mathrm{~kg}$ ha $^{-1} \mathrm{yr}^{-1}$ and 2512.67 and $2275.37 \mathrm{~kg} \mathrm{ha}^{-1} \mathrm{yr}^{-1}$ with and without supplementary feed respectively. Gupta et al. (1990) reported 4917 and 2583 kg $\mathrm{ha}^{-1} \mathrm{yr}^{1}$ productions with and without supplementary feed respectively. Rahman (1997) also obtained 7903 and 3374 kg ha- ${ }^{-1} \mathrm{yr}^{1}$ productions with and without supplementary feed respectively. The results of fish productions with and without supplementary feeding obtained by Murty et al. (1978), Gupta et al. (1990) and Rahman (1997) are similar to those of the present research work. Higher production of fishes was found in T1 where fishes were fed with supplementary feed. Highly significant difference in the production of fishes was found between T1 (with supply of supplementary feed) and T2 (without supply of supplementary feed). Higher fish productions from the ponds with supply of supplementary feed than those of the ponds without supply of supplementary feed were also observed by Chaudhuri et al. (1975), Singh and Singh (1975), Chakrabarty et al. (1976) and Gupta et al. (1990). Khan and J hingran (1975), Gupta et al. (1990), Rahman (1997) reported double yield of fish of the ponds with supply of supplementary feed than that of the ponds having no supplementary feed. In the present study, more than two folds of yield of fish were obtained in the ponds of having supplementary feeding than that of the ponds without supplementary feed. Singh and Singh (1975) obtained 3 to 4 times yield from supplementary feeding ponds than that of the ponds without supplementary feeding. About four folds of yield from supplementary feeding ponds than that of the ponds without supplementary feeding were also found by Hepher et al. (1971). In another study, Chaudhuri et al. (1978) reported seven folds of yield from supplementary feeding ponds than that of the ponds without supplementary feeding.

In conclusion, effects of artificial feeds on the growth and production of fishes along with some limnological conditions were conducted in polyculture system under two treatments. In T1, the fishes were reared with artificial feeding and fertilization and in T2, fishes were reared with only fertilization. Physico-chemical and biological parameters were more or less similar in the ponds under two treatments and were within suitable ranges. The net fish production was more than two times higher in T1 compared to T2 indicated that artificial feeding might play a vital role in pond fish culture to increase production of fishes in polyculture system. 


\section{References}

Alikunhi, K.H. 1957. Fish culture in India. F.M. Bull. Indian Coun. Agric. Res. 20: 144.

APHA. 1992. Standard Methods for the Examination of Water and Wastewater. American Public Health Association, Washington DC. p. 874.

Belcher, H. and Swale, E. 1978. A Beginner's Guide to Freshwater Algae. HMSO, London. $47 \mathrm{p}$.

Chakrabarty, R.D., Sen, P.R., Rao, N.G.S. and Ghosh, S.R. 1976. Intensive culture of Indian major carps. Aqu. Sci. \& Fish. Abs. 6: 12.

Chaudhuri, H., Chakrabarty, R.D., Sen, P.R., Rao, N.G.S. and Jena, S. 1975. A new thought in fish production in India with record yields by composite culture in freshwater ponds. Aquaculture, 5: 343-355.

Chaudhuri, H., Rao, N.G.S., Saha, G.N., Ront, M. and Ranavsia, D.R. 1978. Record of fish production through intensive fish culture in farmer ponds. J. Inland Fish. Soc. India, 10: 19-27.

Chen, T.P. 1976. Aquaculture practices in Taiwan. Fishing News (Books) Ltd., West Byfleet, Surrey, England. 236p.

Chowdhury, M.M.R., Shahjahan, M., Rahman, M.S. and Sadiqul Islam, M. 2008. Duckweed (Lemna minor) as supplementary feed in monoculture of nile tilapia, Oreochromis niloticus. J. Fish. Aqu. Sci. 3: 54-59.

DOF. 2012. Fish week 2012. Department of Fisheries, Ministiy of Fisheries and Livestock. Government of the People's Republic of Bangladesh, Ramna, Dhaka. $123 p$.

Faluroti, E.O. 1987. Performance of fertilization and supplementary feed on fish production under polyculture system in warm water fish ponds. J. West Afr. Fish. 3 (2): 162-170.

Gupta, V.K., Sharma, J.P. and Srivastava, J.B. 1990. Polyculture of Indian and exotic carps using cattle manure with and without supplementary feed. Recent-Trends in Limnol. pp. 439-446.

Hepher, B., Chervinski, T. and Tagari, H. 1971. Studies on carp and silver carp nutrition III. Experiments on the effect on fish of dietary protein source and concentration. Bamidgeh, 23 (1): 11-37.

Hickling, C.F. 1968. The Farming of Fish, 1st ed., Pergamon Press Ltd., Oxford, 88p.

Khan, H.A. and J hingran, V.G. 1975. Synopsis of biological data on rohu, Labeo rohita
(Hamilton, 1822). FAO, Fish. Synop., (III): $100 \mathrm{p}$.

Murty, D.S., Salia, G.N., Selveraj, C., Reddy, P.V.G.K. and Dey, R.K. 1978. Studies on increased fish production in composite fish culture through nitrogenous fertilization, with and without supplementary feeding. J . Inland Fish. Soc. India, 10: 39-45.

Needham, J.G. and Needham, P.R. 1963. A Guide to Study of Freshwater Biology. 5th Edn., Holden-Day, Inc., San Francisco. 106p.

Nupur, N., Shahjahan, M., Rahman, M.S. and Fatema, M.K. 2013. Abundance of macrozoobenthos in relation to bottom soil textural types and water depth in aquaculture ponds. Int. J. Agril. Res. Innov. \&Tech. 3 (2): 1-6.

Prescott, G.W. 1964. Algae of Western Great Lakes area. Wm. C. Brown Co. Dubuque, IOWA. 946p.

Rahman, A.M. 1997. Effects of artificial feeding on the growth and production of fishes in polyculture. M.S. Thesis. Dept. of Fish. Biol. and Genetics, BAU, Mymensingh. 34p.

Rahman, M.S. 1992. Water Quality Management in Aquaculture. BRAC Prokashana, Mohakhali, Dhaka, Bangladesh. 84p.

Rahman, M.S., Shahjahan, M., Haque, M.M. and Khan, S. 2012. Control of euglenophyte bloom and fish production enhancement using duckweed and lime. Iranian J. Fish. Sci. 11: 358-371.

Reid, G.K. 1971. Ecology of Inland Waters and Estuaries. Reinhold Publishing Corporation, New York, Amsterdam. 767p.

Siddika, F., Shahjahan, M. and Rahman, M.S. 2012. Abundance of plankton population densities in relation to bottom soil textural types in aquaculture ponds. Int. J. Agril. Res. Innov. \& Tech. 2 (1): 56-61.

Singh, G.S. and Singh, K.P. 1975. Feeding experiments on Indian major carps in Taraj ponds. J. Inland Fish. Soc. India, 7: 212-21.

Talukdar, M.Z.H., Shahjahan, M. and Rahman, M.S. 2012. Suitability of duckweed (Lemna minor) as feed for fish in polyculture system. Int. J. Agril. Res. Innov. \& Tech. 2 (1): $42-46$.

Uddin, M.N., Rahman, M.S. and Shahjahan, M. 2007. Effects of duckweed (Lemna minor) as supplementary feed on monoculture of GIFT strain of tilapia (Oreochromis niloticus). Prog. Agric. 18: 183-188.

Uddin, M.N., Shahjahan, M. and Haque, M.M. 2012. Manipulation of species composition in small scale carp polyculture to enhance fish production. Bangladesh J. Prog. Sci. \& Tech. 10: 9-12. 